\title{
High-Tech Businesses Management Based on the Trends of Explicit and Implicit Knowledge Markets
}

\author{
Gumerova G. I. ${ }^{1}$, Safiullin M. R. ${ }^{2}$ \& Shaimieva E. Sh. ${ }^{3}$ \\ ${ }^{1}$ The Foundation of infrastructure and educational programs (RUSNANO), Head of the Department of \\ educational projects, Agency for educational projects and programs, Moscow, Russia \\ ${ }^{2}$ Kazan Federal University, Institute of Management, Economics and Finance, Kazan, Russia \\ ${ }^{3}$ Institute of Economics, Management and Law, Kazan, Russian Federation \\ Correspondence: Gumerova G. I., The Foundation of infrastructure and educational programs (RUSNANO), \\ Head of the Department of educational projects, Agency for educational projects and programs, Moscow, \\ Russia.
}

Received: March 10, 2015 Accepted: March 31, 2015 Online Published: April 30, 2015

doi:10.5539/ass.v11n11p239 URL: http://dx.doi.org/10.5539/ass.v11n11p239

\begin{abstract}
The research presents a model of high-tech businesses management, basing on the trends of explicit and explicit knowledge market; classification of high-tech businesses, taking into consideration the three types of economic activity: high-, middle- and low-tech; possibilities to manage the life span of high-tech business basing on its market value, technological innovations costs and business indicators. The research is based upon: authors' methodology of explicit and implicit knowledge market analysis; methodology of classification of the types of industrial production and science-intensive services; the knowledge management model; methodological materials of the Russian Agency on Statistics (Rosstat), statistical data of the National research university "Higher School of Economics".
\end{abstract}

Keywords: management model; high-tech businesses, explicit and implicit knowledge market, classification of high-tech businesses

\section{Topicality}

The development of knowledge market as an integrity of explicit and implicit knowledge markets is a characteristics of the fifth and sixth knowledge-intensive technological patterns on the particular industrial-technological territory (country or region). Solving the topical issues of high-tech business management in enterprises functioning in the international knowledge market and forming the Russian market of explicit and implicit knowledge will promote the priority of high-tech business development. The program document of "Strategy of innovative development of the Russian Federation up to 2020" "Methodology of calculation of indicators "Share of the production of high-tech and science-intensive sectors in the gross domestic product" does not sufficiently highlight the criteria of development for high-tech business, science-intensive companies and science-intensive services. The high-tech business models have barriers for high-tech business development both in the age of a high-tech business and type of its economic activity (Top 50 of "TekhUspekh" rating). International ratings of high-tech businesses: Thomson Reuters (USA) (2013); indexes of high-tech business: Nasdaq (USA), DAX (Germany) include companies not functioning in high- and middle-tech business types of economic activity (Official web-site of Nasdaq; Predstavlyayushchiy broker company). The research of this fact will allow to reveal the notion of "high-tech businesses" (Acemoglu, 2010; Aranguren \& Larrea, 2011).

\section{Methodology}

The authors have elaborated the approach to research the high-tech businesses management, basing on the knowledge market analysis at macro- meso- and micro-levels, the model of knowledge management in an organization (Table 1, Figure 1).

The authors' business model of high-tech businesses is based on regulating the high-tech businesses' functioning on the markets of high-, middle- and low-tech production by managing the business indicators and expenses on technological innovations (Betz, 2014; Carayannis \& Papadopoulos, 2011; Giudice, Peruta, \& Maggioni, 2013). 
The critical positions are $[\mathrm{O}, \mathrm{Y} 1, \mathrm{Y} 2],[\mathrm{O}, \mathrm{X} 1, \mathrm{X} 2]$. In the first case the life span of a high-tech business is ensured by the efficient management system, which is bound to fail short-term without expenses on technological innovations. In the second case, the massive expenses on (technological) innovations lead to bankruptcy, though there are patents and the brand, but there is no appropriate management system, business model and knowledge management in the organization (Gumerova \& Shaymieva, 2014; Gumerova \& Shaymieva, 2013; Herstad, Pålshaugen, \& Ebersberger, 2011).

Table 1. Methodology of knowledge management research: methodology of analysis of explicit and implicit knowledge markets according to the authors' research (2013; methodology of classification of industrial production and science-intensive services based on OECD methodology

Methodology of Analysis of Explicit and Implicit Knowledge
Market

2. MESOLEVEL: methodology and analysis of export and import of technology and services of technical character at the federal districts level; patent applications and protection documents in the industrially developed mesosystems of Russia

2a. Explicit knowledge market: patent applications; issue of protection documents (units)

2b. Implicit knowledge market: export of technology and services of technical character (units, thousand US dollars); import of technology and services of technical character (units, thousand US dollars);

3. MICROLEVEL: methodology and analysis of explicit and implicit knowledge management basing on the analysis of expenses for technological innovations in the Russian industrial enterprises *

3a. Explicit knowledge market: acquiring new technologies: rights for patents, licenses, useful models, industrial samples (mln rub.)

3b. Implicit knowledge market: research and elaboration of products, services and methods of their production, new production processes ( $\mathrm{mln}$ rub.); industrial projecting, design (mln rub.); teaching and training of personnel, connected with innovations (mln rub.); marketing research ( $\mathrm{mln}$ rub.)

Methodology of Classification of Industrial
Production and Science-Consuming Services

0. Comparative analysis of codes of types of economic activity in industrial production and science-intensive services by OECD and Rosstat;

\section{INDUSTRIAL PRODUCTION}

1. Analysis of types of industrial production according to OECD

2. Analysis of types of industrial production according to Rosstat

3. Formulating the criteria for classifying the types of industrial production

4. Formulating the classification of the types of industrial production based on OECD methodology, on Rosstat classification

\section{SCIENCE-CONSUMING SERVICES}

1. Analysis of types of science-intensive services according to OECD ;

1a. Formulating the criteria for classifying the science-intensive services

2. Analysis of types of science-intensive services according to Rosstat;

2a. Analysis of the evolution of science-intensive services classification in 2011-2014;

26. Forming: (a) a block of types of science-intensive services, which are mentioned in the documents on high-tech business development; (b) a block of types of science-intensive services, which are not mentioned in such documents

3. Formulating the classification of knowledge-based services based on OECD methodology, on Rosstat classification

Source: on the basis of (Gumerova \& Shaymieva, 2013; 2014)

Table 2. High-tech business index: correlation of the company value; intellectual property objects; material assets to the life span of the company

\begin{tabular}{|c|c|c|}
\hline $\begin{array}{l}\text { Correlation } \\
\text { VE/ life span of an enterprise }=\end{array}$ & $\begin{array}{l}\text { market value of company } \\
\text { life span of an enterprise }\end{array}$ & (1), \\
\hline $\begin{array}{l}\text { Correlation } \\
\text { VIPO/ life span of an enterprise }=\end{array}$ & $\begin{array}{l}\text { value of intellectual property of the company } \\
\text { life span of an enterprise }\end{array}$ & (2), \\
\hline $\begin{array}{l}\text { Correlation } \\
\text { VMA/ life span of an enterprise }=\end{array}$ & $\begin{array}{l}\text { value of material assets of the company } \\
\text { life span of an enterprise }\end{array}$ & (3) \\
\hline
\end{tabular}




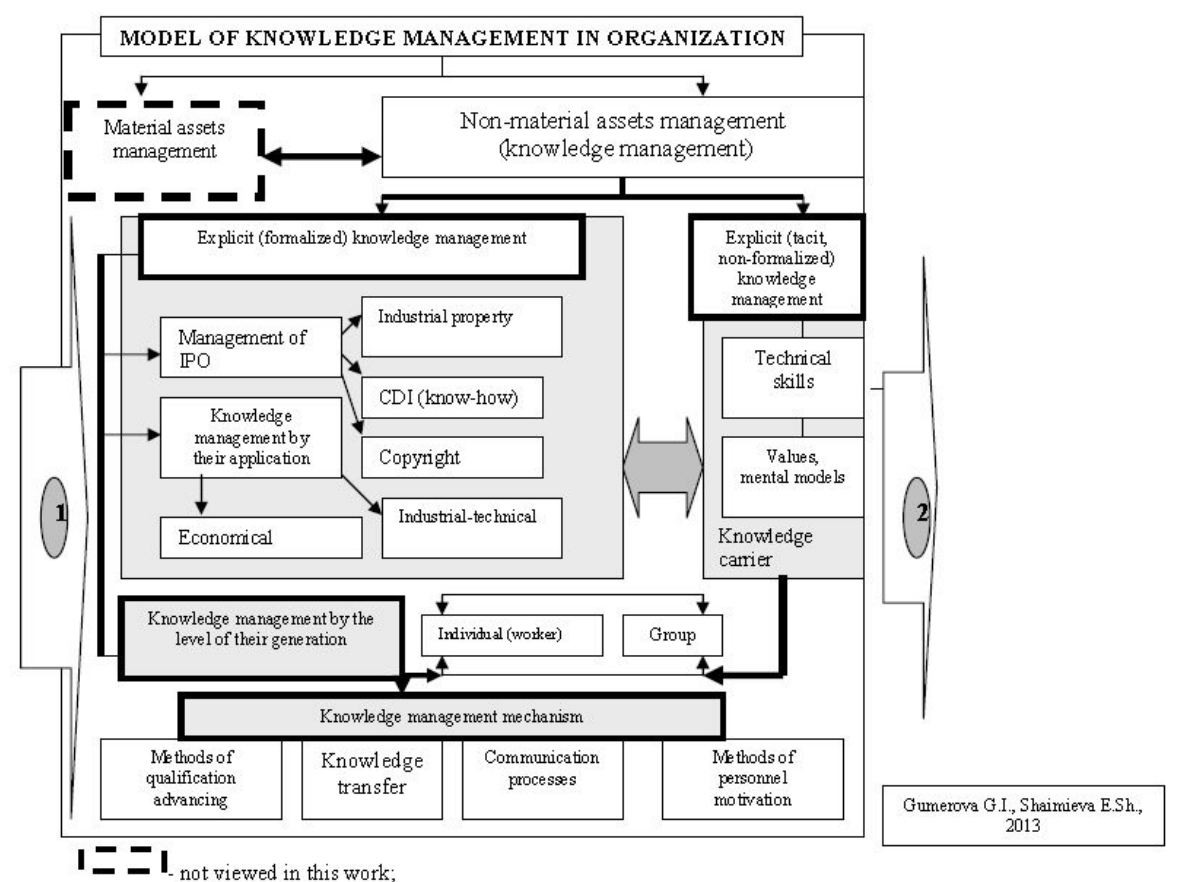

IPO - intellectual property objects; CDI - confidential documented information;

(1) - resources at the "entrance" of organiza (2) products and services at the "exit" of organization

Source: on the basis of (Gumerova \& Shaymieva, 2013; 2014)

Figure 1. Model of knowledge management in organization: theoretical aspect

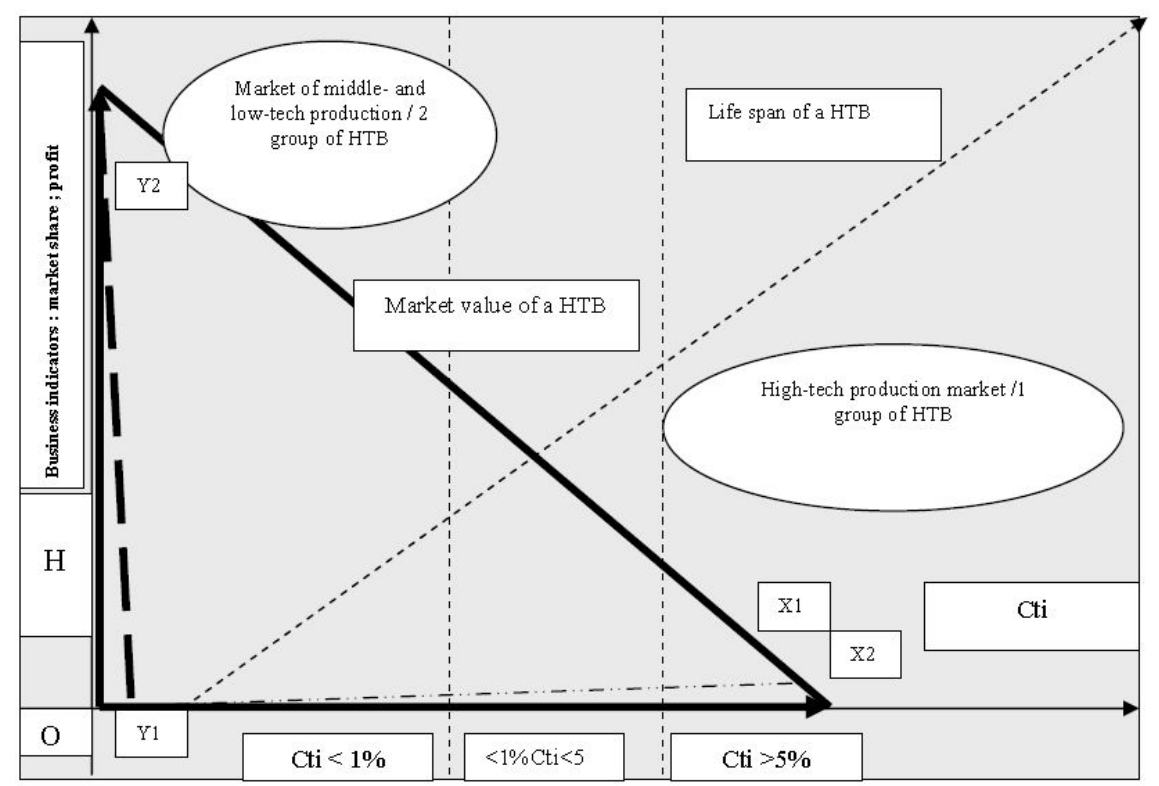

HTB - high-tech businesses; TI - technological innovations;

$\mathrm{H}$ - business indicators depending on TEA

$\mathrm{Cti}$ - expenses for innovations to the turnover (\%)

фигура [O,Y1,Y2] - critical position for enterprises of 2 group of high-tech business; фигура [O, X1, X2] - critical position for enterprises of 1 group of high-tech business

Figure 2. Business model of high-tech businesses: expenses for technological innovations, business indicators based on (Gumerova \& Shaymieva, 2013; 2014) 
The space optimal for high-tech businesses functioning is [Y1,Y2,X1] (Diagram 1): cost management of a high-tech business is carried out long-term with expanding expenses on technological innovations and strengthening business indicators. An additional tool for analyzing the high-tech businesses management is an index of high-technology of high-tech businesses, which is a complex of three equations in the sphere of high-tech businesses management (Diagram 1). Interpretation of the analysis of high-tech business index is as follows: I. At the level of three indicators of high-tech business index: analysis of data and revealing the causes of the company value at the expense of intellectual property objects or material assets during the life span of an enterprise. II. At the level of indicators of correlation between company value, intellectual property objects value and the life span of an enterprise: (a) if the life spans of the analyzed companies are equal, more efficient is the company with the larger high-tech business index; (b) if the spans of the analyzed companies are not equal, it is necessary to find the mean value, making groups with closest values (Jones, 1995).

\section{Research Results}

The elaborated model of knowledge management, the technique of explicit and implicit knowledge markets analysis is productive for developing and confirming the ideas represented in the works by Nonaka and Takeuchi on the significance and dominating of implicit knowledge in the knowledge market and in the organization as a whole (Table 1) (Isaksen \& Karlsen, 2011). Basing on the authors' methodology of the analysis of explicit and implicit knowledge market, the knowledge management model in an organization as a result of knowledge market development as an integrity of explicit and implicit knowledge markets in the Russian Federation (RF) in 2000-2010, the following conclusions are made:

- in 2000-2010, implicit knowledge market (export and import of implicit knowledge) dominated in the development of knowledge markets in RF; maximal values in the development of knowledge markets in RF were achieved in 2008 on the basis of maximal values of export and import of implicit knowledge (Figure 3); the worst values in the researched period were shown by the market of explicit knowledge export (in quantitative indicators by years, by the volume of growth) (Gumerova \& Shaymieva, 2013; 2014; Herstad, Pålshaugen, \& Ebersberger, 2011).

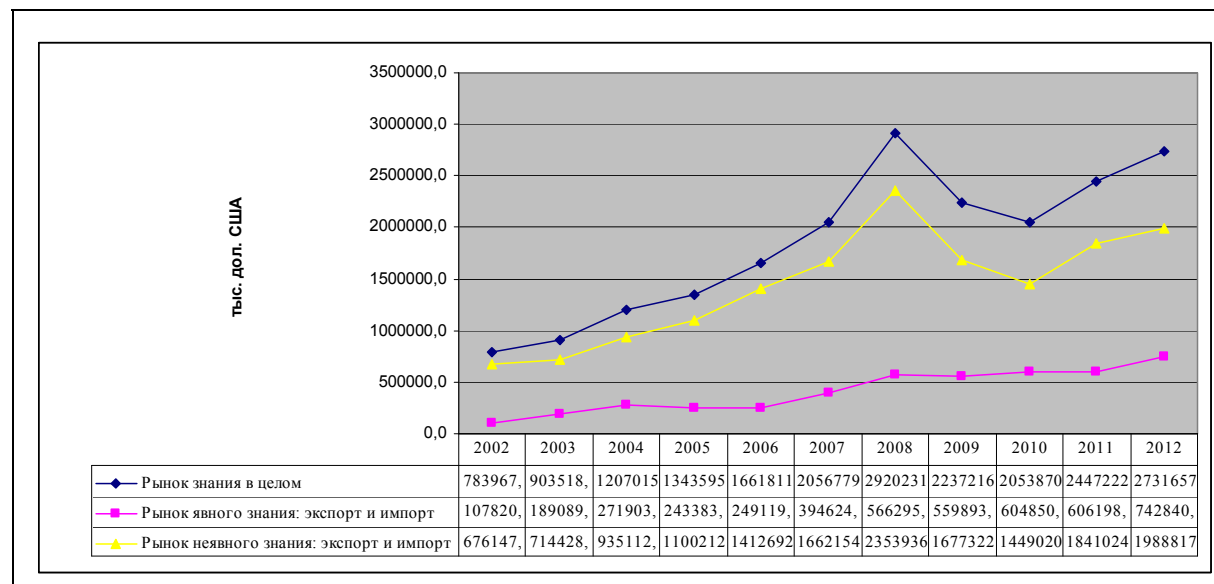

Methodology of estimating the
volumes of knowledge markets by
types of knowledge as a type of
foreign economic activity of RF
enterprises in 2002-2012.
(a) volume of whole knowledge
market in RF is defined as a sum
of export and import markets of
explicit and implicit knowledge;
(b) volume of explicit knowledge
market in RF is defined as income
from export and import of explicit
knowledge;
(c) volume of implicit knowledge
market in RF is defined as
payments for export and import of
explicit and implicit knowledge

Source: on the basis of (Gumerova \& Shaymieva, 2013; 2014; Herstad, Pålshaugen, \& Ebersberger, 2011)

Figure 2. Volumes of knowledge markets by types of knowledge as a type of foreign economic activity of RF enterprises in 2002-2012: knowledge market as a whole (sums of export and import of explicit and implicit knowledge; export of explicit and implicit knowledge; import of explicit and implicit knowledge), thousand US dollars.

The dominant of the Russian knowledge market in 2000-2010 is the following processes: import and export of non-formalized knowledge. The engineering services import within the implicit knowledge implies modernization of obsolete equipment and non-material assets. Besides, if the equipment is transferred by a transnational corporation, then only knowledge of servicing is transferred (by license agreements), not the know-how (Romer, 1990; Teece, 1981 \& 1996). The export implies rendering engineering services (within the implicit knowledge) by the Russian specialists without the corresponding sales of the Russian equipment (Gumerova \& Shaymieva, 2013). Having revealed the trends of the Russian knowledge market in 2000-2010, we should investigate the following issues: classification of high-tech businesses; analysis of business models implemented in the knowledge markets elaborating the knowledge for high-tech businesses of various groups. 
High-tech businesses are three groups of companies: the first group is engaged in high-tech and science-intensive type of economic activity. According to (Ajupov, Mishina, \& Ivanov, 2014), the criteria of attributing a business to high-tech sectors is a high level of technological development, defined as the ratio of scientific research costs to the gross added value. The criteria of attributing a sector to the science-intensive ones is the share of employees with a high level of professional education in the overall number of employees; the second group is engaged in middle- and low-tech type of economic activity, implementing high-tech businesses management, which results in the high level of technological development of the enterprise (Figure 3, Appendix 1).

This is achieved, first of all, by a business model (or managerial knowledge) implemented in those enterprises. The third group is mixed, where: (a) enterprises can have simultaneously high expenses on technological innovations, high business organization, and function in low-tech types of economic activities; (b) science-intensive businesses, whose functioning can be attributed to the first and second group. The common criteria of high-tech businesses are: (1) high market value of the company, based on the knowledge economy objects management: enterprise brand, explicit and implicit knowledge, personnel; (2) life span of the company. Thus, high-tech businesses are enterprises obtaining profit from the company cost management regardless of their type of economic activity (low-, middle- or high-technological).

The scientific-practical application of the authors' theoretical provisions is the analysis of the management of intellectual property objects in football clubs as high-tech businesses. This activity - code 92.6 by the Russian classificator of types of economic activity - "Activity in the sphere of sport" is researched only for the extended indicator "Share of the production of high-tech and science-intensive sectors in the gross domestic product compared with the indicator recommended for OECD members". The research shows how knowledge economy tools are used for enterprise management (in foreign football clubs) and the lack or absence of such tools (Russian football clubs).
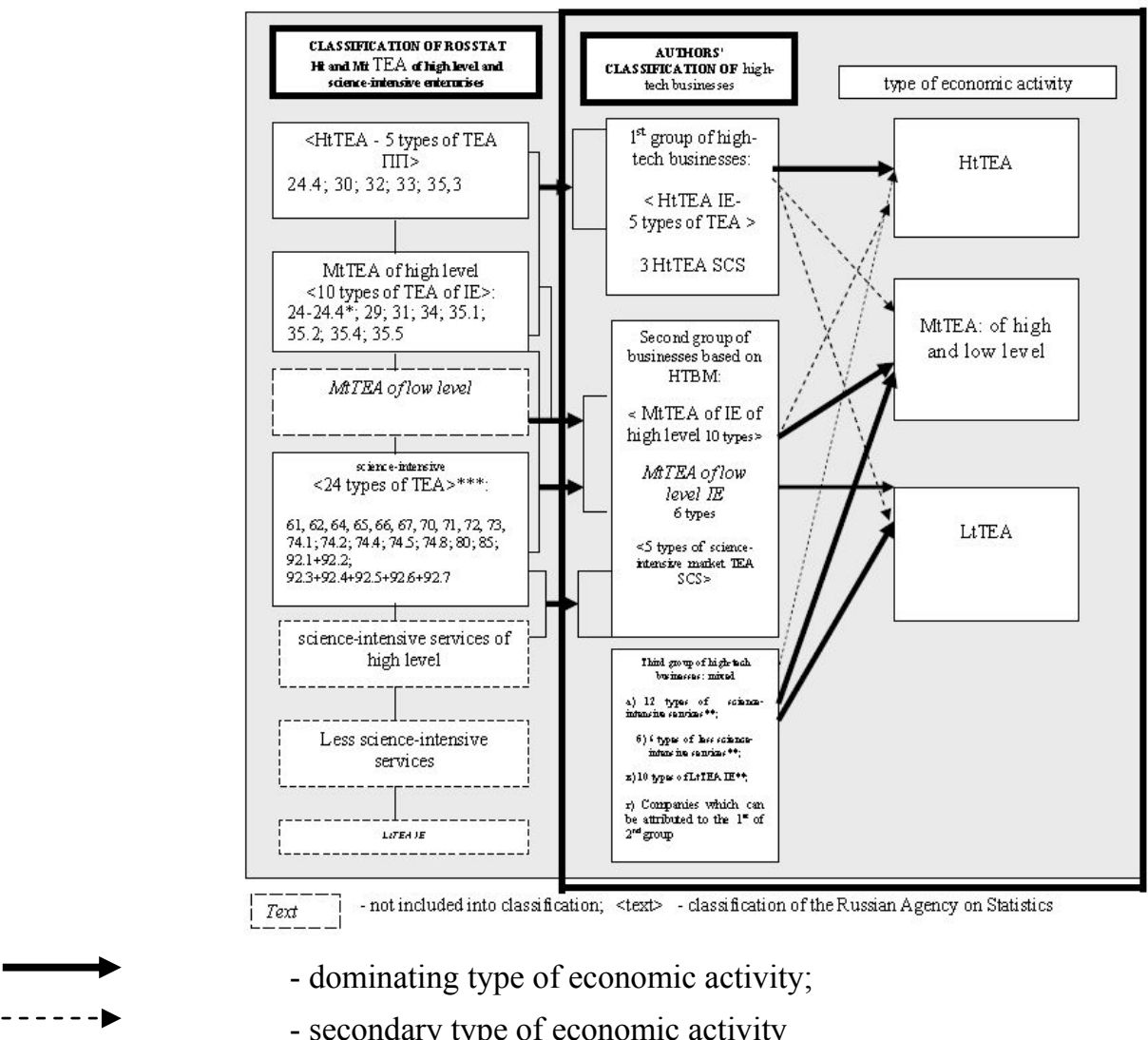

- dominating type of economic activity;

- secondary type of economic activity

* - 24.4. - pharmaceutical production, excluding 24.4.

** - high cost of the company;

*** - both subsectors and constituents as separate type of economic activity

[30] - subsector from the Russian classificator of types of economic activity;

24.2. - constituent of a subsector 
HTB - high-tech businesses

HTA - high-tech activity

TEA - type of economic activity

HTBM - high-tech business management
IE - industrial enterprises

SCS - science-intensive services

LtTEA - low-tech type of economic activity

MtTEA - middle-tech type of economic activity

Source: on the basis of: (Ajupov, Mishina, \& Ivanov, 2014; Gumerova \& Shaymieva, 2014)

Figure 3. Classification of high-tech businesses (author's know-how)

The analysis of high-tech business index according to the authors' technique showed that in 2012 there were two groups of clubs: with life span from 100 to 150 years and from 50 to 100 years. The first group of clubs includes mainly foreign football clubs: Manchester United, Bavaria, Real, Barcelona. The second group includes Russian football clubs: Zenit, Spartak, Shakhter (Figure 4). We see that the value of the Russian football clubs during the whole period of their functioning is the value of their material assets, i.e. the material-technical base without the knowledge-intensive component of knowledge economy (Figure 4). When managing a football club as a material asset only, there is no business model of company management as a complex of material and non-material assets management, which is the constituent part of the science-intensive service - activity in the sphere of sports by the authors' classification of high-tech businesses, the trends of explicit and implicit knowledge market are not taken into account. The high-tech businesses management on the basis of trends of explicit and implicit knowledge market allows to introduce the parameter "life span of the company". If the company value increases, this parameter is an obligatory indicator of its business model, reflecting the constructive activity of the highly qualified personnel creating and implementing the explicit and implicit knowledge in the market, within the knowledge management system in the organization. That promotes the company value growth in the knowledge market long-term.

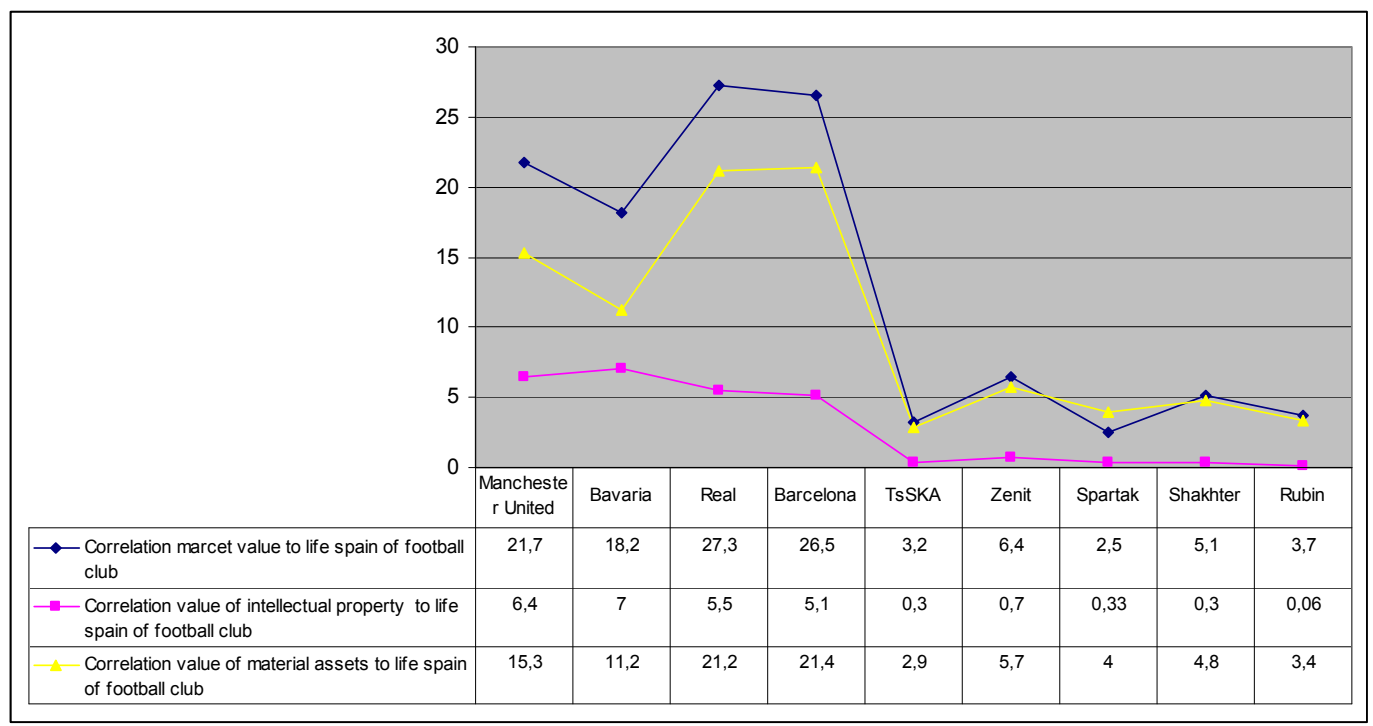

IPO - intellectual property object; FC - football club; VFC - value of football club; VIPO - value of intellectual property objects; VMA - value of material assets;

Figure 4. High-tech business indexes of foreign and Russian football clubs (2012)

\section{Conclusions}

The following scientific-theoretical and scientific-practical conclusions are made:

1. The work differentiates the notion of "high-tech business", distinguishing three groups of enterprises.

2. Classification of high-tech businesses is proposed, taking into account the three types of economic activity, which allows to include high-tech businesses with high market value.

3. The proposed business model of the interaction between enterprises functioning in the high-, middle- and low-tech markets implies the possibility to manage the life span of the company basing on its value, expenses on technological innovations and business indicators. 


\section{References}

Acemoglu, D. (2010). When Does Labor Scarcity Encourage Innovation? Journal of Political Economy, 118, 1037-1078.

Ajupov, A. A., Mishina, M. S., \& Ivanov, M. E. (2014). Method of valuation of financial factors influencing the implementation of liquidity risk for leasing companies. Mediterranean Journal of Social Sciences, 5(24), 154-159.

Aranguren, M. J., \& Larrea, M. (2011). Regional Innovation Policy Processes: Linking Learning to Action. Journal of the Knowledge Economy, 2, 569-585.

Betz, F. (2014). Control in Knowledge Economies. Journal of the Knowledge Economy, 5, 761-783.

Carayannis, E. G., \& Papadopoulos, C. B. (2011). The Innovation Diplomacy Concept and the Hellenic-American Innovation Bridge as a Special Case-in-Point. Journal of the Knowledge Economy, 2(3), 257-326.

Giudice, M. D., Peruta, M. R. D., \& Maggioni, V. (2013). Collective Knowledge and Organizational Routines within Academic Communities of Practice: an Empirical Research on Science-Entrepreneurs. Journal of the Knowledge Economy, 4, 260-278.

Gumerova, G. I., \& Shaymieva, E. Sh. (2013). Sovremennyie tendentsii razvitiya ryinka yavnyih i neyavnyih znaniy v promyishlenno-razvityih regionah Rossiyskoy Federatsii. Investiii v Rossii, 9, 37-48.

Gumerova, G. I., \& Shaymieva, E. Sh. (2014). Upravlenie znaniem v organizatsii: indikator funktsionirovaniya sistemyi, tendentsii v rossiyskoy ekonomike. Ekonomika v promyishlennosti, 2(22), 37-48.

Herstad, S., Pålshaugen, Ø., \& Ebersberger, B. (2011). Industrial Innovation Collaboration in a Capital Region Context. Journal of the Knowledge Economy, 2, 507-532.

Herstad, S., Pålshaugen, Ø., \& Ebersberger, B. (2011). Industrial Innovation Collaboration in a Capital Region Context. Journal of the Knowledge Economy, 2(4), 507-532.

Humphrey, B. R., \& Ruseski, J. E. (2010). Problems With Data on the Sport Industry. Journal of Sports Economics, 11(1), 60-76.

International football rating. Retrieved from http://www.footballtop.ru/

Isaksen, A., \& Karlsen, J. (2011). Organisational Learning, Supportive Innovation Systems and Implications for Policy Formulation. Journal of the Knowledge Economy, 2(4), 453-462.

Jones, Ch. (1995). R\&D-Based Model of Economic Growth. Journal of Political Economy, 103(4).

Kazunobu, O. (2012). Korporativnaya strategiya v vyisokotehnologichnyih kompaniyah. Vestnik Nizhegorodskogo universiteta im. N.I. Lobachevskogo. Seriya Sotsialnyie nauki, 3, 60-65.

Kiselev, S. V., \& Muryasova, A. R. (2012). Upravlenie stoimostyu firmyi. Vestnik Kazanskogo tehnologicheskogo universiteta, 15(19), 283-288.

Kramin, T. V., \& Tsertseil, Yu. S. (2008). Sovershenstvovanie upravleniya stoimostyu na osnove klasternogo podhoda $\mathrm{v}$ institutsionalnoy ekonomike. Aktualnyie problemyi ekonomiki i prava, 4, 73-81.

Official web-site of "Predstavlyayushchiy broker" company. Retrieved from http://evotrade.ru/indices/dax/

Official web-site of Nasdaq. Retrieved from http://www.nasdaq.com/symbol/wfm

Romer, P. M. (1990). Endogenes Technological Change. Journal of Political Economy.

Sung, Y. T., \& Tainsky, S. (2014). The National Football League Wagering Market: Simple Strategies and Bye Week-Related Inefficiencies. Journal of Sports Economics August, 15(4), 365-384.

Teece, D. J. (1981). The Market for Know-How and the Efficient International Transfer of Technology. Annuals of the American Association of Political and Social Sciences.

Teece, D. J. (1996). Firm Organization, Industrial Structure and Technological Innovation. Journal of Economic Behavior and Organization, 31(2), 193-224.

Temel, B. (2014). Book Review: The Oxford handbook of sports economics: The economics of sports and The Oxford handbook of sports economics: Economics through sports. Journal of Sports Economics, 15(6), 650-653.

Thomson Reuters 2013 Top 100 global innovators. Honoring The World leaders in innovation. Findings and 
methodology. October 2013. Retrieved from http://top100innovators.com/top100-2013.pdf

Top 50 of "TekhUspekh" rating. National rating of the most rapidly developing Russian high-tech businesses according to "TekhUspekh". Retrieved from http://www.ratingtechup.ru/rate/

\section{Notes}

Note 1. Issues of cost management are researched by (Kiselev \& Muryasova, 2012; Kramin \& Tsertseil, 2008; Kazunobu, 2012)

Note 2. Examples of the 1.st group companies are: hardware manufacturers, software developers; access \& content providers; e-commerce, etc. (Gumerova \& Shaymieva, 2014; Gumerova \& Shaymieva, 2013)

Note 3. Depending on the sphere of research and patents in proper types of economic activity. Besides, it should be noted that this group can be divided into two subgroups (this is confirmed in the practical section of the research).

\section{Appendix 1}

Table 2. Types of economic activity of high-tech businesses according to the List of Types of economic activity of Rosstat": industrial production and science-intensive services

\begin{tabular}{|c|c|c|c|c|c|}
\hline \multicolumn{2}{|c|}{$\begin{array}{lcc}5 & \text { types of } & \text { high } \\
\text { technological level } & \end{array}$} & \multicolumn{2}{|c|}{$\begin{array}{l}10 \text { types of middle technological } \\
\text { types of activity of high level }\end{array}$} & \multicolumn{2}{|c|}{24 science-intensive types of activity } \\
\hline \multicolumn{2}{|r|}{$\mathbf{I}$} & \multicolumn{2}{|r|}{ II } & \multicolumn{2}{|r|}{ III } \\
\hline A & Sector & A & Sector & A & Sector \\
\hline \multirow[t]{3}{*}{24.4} & \multirow{3}{*}{$\begin{array}{l}\text { Pharmaceutical } \\
\text { production }\end{array}$} & \multirow{2}{*}{$\begin{array}{l}{[24]-2} \\
4.1-2 \\
4.2-2 \\
4.3\end{array}$} & \multirow{2}{*}{$\begin{array}{l}\text { Chemical production, } \\
\text { excluding } \\
\text { pharmaceutical } \\
\text { production }\end{array}$} & [61] & Water transport \\
\hline & & & & [62] & Air and space transport \\
\hline & & \multirow[t]{2}{*}{ [29] } & \multirow{2}{*}{$\begin{array}{l}\text { Production of machines } \\
\text { and equipment }\end{array}$} & [64] & Communication \\
\hline \multirow[t]{5}{*}[30]{} & \multirow{5}{*}{$\begin{array}{l}\text { Production of } \\
\text { office equipment } \\
\text { and computing } \\
\text { appliances }\end{array}$} & & & [65] & Financial agency \\
\hline & & {$[31]$} & $\begin{array}{lr}\text { Production } & \text { of electric } \\
\text { machines } & \text { and } \\
\text { equipment } & \end{array}$ & [66] & Insurance \\
\hline & & \multirow[t]{6}{*}{ [34] } & \multirow[t]{6}{*}{$\begin{array}{l}\text { Production of } \\
\text { automobiles and trailers }\end{array}$} & [67] & $\begin{array}{l}\text { Auxiliary activity in the sphere of financial } \\
\text { agency and insurance }\end{array}$ \\
\hline & & & & [70] & Real estate operations \\
\hline & & & & [71] & $\begin{array}{l}\text { Renting of machines and equipment without } \\
\text { operators; renting household appliances and } \\
\text { personal belongings }\end{array}$ \\
\hline \multirow[t]{3}{*}{ [32] } & \multirow{3}{*}{$\begin{array}{l}\text { Production of } \\
\text { electronic } \\
\text { components, } \\
\text { equipment for } \\
\text { radio, television } \\
\text { and communication }\end{array}$} & & & [72] & 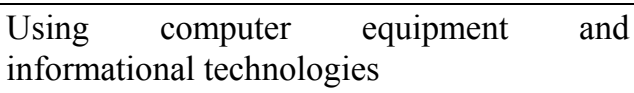 \\
\hline & & & & [73] & Scientific research and development \\
\hline & & & & 74.1 & $\begin{array}{l}\text { Activity in the sphere of law, accounting, } \\
\text { and audit; consulting in commercial activity } \\
\text { and business management }\end{array}$ \\
\hline [33] & $\begin{array}{lr}\text { Production } & \text { of } \\
\text { medical devices; } \\
\text { measuring and } \\
\text { controlling } \\
\text { equipment, } \\
\text { equipment for } \\
\text { managing and }\end{array}$ & $\begin{array}{l}35.2+ \\
35.4+ \\
35.5\end{array}$ & $\begin{array}{l}\text { Production of railway } \\
\text { vehicles (locomotives, } \\
\text { tram cars, etc.); } \\
\text { Production } \quad \text { of } \\
\text { motorcycles and } \\
\text { bicycles; Production of } \\
\text { other transportation }\end{array}$ & 74.2 & $\begin{array}{l}\text { Activity in the sphere of architecture; } \\
\text { engineering-technical projecting; geological } \\
\text { and geophysical works; } \\
\text { Geodesic and cartographic activity; activity } \\
\text { in the sphere of standardization and } \\
\text { metrology; activity in the sphere of } \\
\text { hydrometrology and adjacent spheres; }\end{array}$ \\
\hline
\end{tabular}




\begin{tabular}{|c|c|c|c|c|}
\hline & $\begin{array}{l}\text { testing; optical } \\
\text { devices, photo- and } \\
\text { video-equipment; } \\
\text { watches }\end{array}$ & $\begin{array}{l}\text { vehicles outside other } \\
\text { groups }\end{array}$ & & $\begin{array}{l}\text { activity in the sphere of technical tasks, not } \\
\text { included in other groups }\end{array}$ \\
\hline \multirow[t]{7}{*}{35.3} & \multirow{7}{*}{$\begin{array}{lr}\begin{array}{l}\text { Production } \\
\text { of } \\
\text { airships } \\
\text { spaceships }\end{array} & \text { and } \\
\end{array}$} & & 74.4 & Advertising activity \\
\hline & & & 74.5 & Employment and selecting of personnel \\
\hline & & & 74.8 & Rendering various services \\
\hline & & & [80] & Education \\
\hline & & & [85] & Health care and rendering of social services \\
\hline & & & $\begin{array}{l}92.1+ \\
92.2\end{array}$ & $\begin{array}{l}\text { Activity in the sphere of production and } \\
\text { demonstration of films, activity in the } \\
\text { sphere of radio and television broadcasting }\end{array}$ \\
\hline & & & $\begin{array}{l}92.3+ \\
92.4+ \\
92.5^{+} \\
92.6^{+} \\
92.7\end{array}$ & $\begin{array}{l}\text { Other entertainment activity; activity of } \\
\text { information agencies; other activity in the } \\
\text { sphere of culture; activity in the sphere of } \\
\text { sport; other activity in the sphere of rest and } \\
\text { entertainment }\end{array}$ \\
\hline
\end{tabular}

\section{Copyrights}

Copyright for this article is retained by the author(s), with first publication rights granted to the journal.

This is an open-access article distributed under the terms and conditions of the Creative Commons Attribution license (http://creativecommons.org/licenses/by/3.0/). 